\title{
NGHIÊN CƯU SÀNG LỌC KHÁNG THỂ BÂT THƯỜNG Ở BỆNH NHÂN TRƯớC PHẪU THUẬT TẠI TRUNG TÂM TIM MẠCH BỆNH VIỆN E TỪ THÁNG 7 NĂM 2013 ĐẾN THÁNG 8 NĂM 2014
}

Đào Thị Thanh Nga*, Lê Ngọc Linh*, Luoong Thị Anh*

\section{TÓM TÁT}

Sàng lọc kháng thể bất thường là xét nghiệm cần thiết đảm bảo trong an toàn truyền máu và giảm thiểu phản ứng chậm sau truyền máu.

Trong nghiên cứu sàng lọc kháng thể bất thường ở bệnh nhân trước phẫu thuật tại Trung tâm tim mạch - Bệnh viện $\mathrm{E}$ trung ương từ tháng 7 năm 2013 đến tháng 8 năm 2014 , tổng số 1680 trường hợp (832 nam, 848 nữ), 11 trường hợp có kết quả dương tính với kháng thể bất thường chiếm tỷ lệ $0,65 \%$. Tỷ lệ dương tính ở bệnh nhân nữ $0,83 \%$ cao hơn so với bệnh nhân nam đáng kể $(0,48 \%)$. Có 176 bệnh nhân từ 0 đến 6 tháng tuổi tỷ lệ dương tính là $1,7 \%$; sau là nhóm tuổi từ 19 đến 40 tuổi tỷ lệ dương tính là $0,97 \%$. Tỷ lệ kháng kháng thể bất thường có liên quan đến tuổi, giới, và chẩn đoán lâm sàng. Nghiên cứu này có vai trò quan trọng của sàng lọc kháng thể bất thường cho bệnh nhân trước phẫu thuật.

\section{SUMMARY}

Study on frequency of irregular-antibody Screening on preoperative patients in cardiovascular centre of $E$ hospital from July 2013 to August 2014

Screening of irregular antibodies is critical for ensuring safe blood transfusion and reducing transfusion reactions in blood recipients. The reported percentages of positive cases of irregular antibodies differ across age, sex, clinical diagnosis. We retrospectively analyzed 1680 inpatients (832 men and 848 women) who received blood transfusions between July 2013 and August 2014 at cardiovascular centre of E Hospital. We screened the irregular antibodies in blood-transfusion recipients by performing Coombs' test. Among the 1680 cases screened during the study period, 11 were positive for irregular antibodies $(0,65 \%)$. The incidence of positive cases among women $(0,83 \%)$ was significantly higher than that that among men $(0.48 \% ; p<0,05)$. Among the 1680 cases screened in this study, 176 were baby between newbore and six months, and the percentage of positive cases among that group (1.7\%) was highest after were group patients between 19 and 40 years old $(0,97 \%)$. The percentages of positive cases of irregular antibodies were slightly different across the different age. The percentage of positive cases in the women, was higher than that in the men; This finding highlighted the critical role of irregular-antibody screening in this population.

\section{I. ĐẶT VẤN ĐỀ}

Trung tâm tim mạch bệnh viện $\mathrm{E}$ điều trị và phẫu thuật các bệnh lý tim mạch lồng ngực.

\footnotetext{
* Trung tâm Tim mạch Bệnh viện E

Nguòi chịu trách nhiệm khoa họ: PGS.TS. Lê Ngọc Thành Ngày nhận bài: 20/03/2015 - Ngày Cho Phép Đăng: 27/03/2015

Phản Biện Khoa học: PGS.TS. Đặng Ngọc Hùng

PGS.TS. Bùi Đức Phú
} 
Cùng với sự phát triển của Trung tâm thì số lượng bệnh nhân với tính chất bệnh lý nặng và phức tạp tăng lên, truyền máu trong phẫu thuật cũng tăng lên đáng kể. Trong phẫu thuật tim mạch, truyền máu rất quan trọng góp phần vào sự thành công của ca bệnh. Truyền máu chỉ hiệu quả khi có sự phù hợp về hoàn toàn về nhóm máu. Ngoài hệ thống kháng nguyên tự nhiên quyết định nhóm máu $A B O$ và $R h$, trên tế bào hồng cầu còn có rất nhiều kháng nguyên protein và carbonhydrate trên bề mặt. Hiện có hơn 600 kháng nguyên , được chia thành hơn 30 hệ thống nhóm máu. Sự hiện diện hay vắng mặt của các kháng nguyên này là rất quan trọng vì nó xác định nhóm máu của từng cá thể.

Ở nhiều nước trên thế giới ngoài việc xác định hòa hợp nhóm máu hệ $\mathrm{ABO}, \mathrm{Rh}$ và một số nhóm máu khác thì xét nghiệm sàng lọc kháng thể bất thường trước truyền máu đã trở thành thường qui bắt buộc. Với những bệnh nhân xác định có kháng thể bất thường sẽ được lựa chọn tìm ra đơn vị máu có kháng nguyên hồng cầu phù hợp.

Tuy vậy truyền máu cũng là sự xâm nhập của kháng nguyên vào cơ thể, sự xuất hiện những phản ứng miễn dịch không mong muốn kháng lại hồng cầu, bạch cầu, hay tiểu cầu và các protein trong máu là điều không thể tránh khỏi. Vì vậy chúng tôi tiến hành nghiên cứu với mục tiêu:

1. Xác định tỷ lệ kháng thể bất thường ở bệnh nhân trước phẫu thuật và truyền máu tại Trung tâm tim mạch - Bệnh viện E.

2. Tỷ lệ kháng thể bất thường liên quan đến tuổi, giới và chẩn đoán lâm sàng.

\section{II. ĐỐI TƯợNG VÀ PHƯƠNG PHÁP NGHIÊN CÚ'U}

2.1. Đối tượng nghiên cứu: 1680 bệnh nhân phẫu thuật điều trị tim mạch tuổi từ 0 tháng đến 85 tuổi tại Trung tâm tim mạch - Bệnh viện $\mathrm{E}$ từ tháng 7 năm 2013 đến tháng 8 năm 2014. Bao gồm: 832 nam, 848 nữ. trong đó 966 bệnh nhân mắc bệnh tim bẩm sinh, 424 bệnh nhân bệnh van tim, 213 bệnh nhân mắc bệnh lý mạch máu, 47 bệnh nhân bệnh lý lồng ngực khác.

- Vật liệu và thuốc thử:

- $4 \mathrm{ml}$ máu của các bệnh nhân trên được lấy vào ống nghiệm không chống đông, ly tâm tách huyết thanh để lám xét nghiệm sàng lọc kháng thể bất thường ngay.

- Thuốc thử: panel hồng cầu đa giá của Viện Huyết học - Truyền máu Trung ương cung cấp.

- Huyết thanh AHG kháng globulin người, anti $\mathrm{D}$, đệm LISS và các kháng huyết thanh chuẩn để xác định nhóm máu của hãng $\mathrm{CE}$.

\subsection{Phương pháp nghiên cứu:}

- Thiết kế nghiên cứu: nghiên cứu mô tả cắt ngang.

- Tiến hành kỹ thuật:

Huyết thanh của bệnh nhân được sàng lọc kháng thể bất thường với Panel hồng cầu của Viện Huyết học - Truyền máu trung ương bằng kỹ thuật ống nghiệm ở $22^{\circ} \mathrm{C}, 37^{\circ} \mathrm{C}$, Coombs gián tiếp. Kết quả được nhận định bằng mắt thường và đọc trên kính hiển vi quang học

- Xử lý kết quả nghiên cứu bằng các phương pháp thống kê toán học. 


\section{KẾT QUẢ NGHIÊN CÚU:}

\subsection{Tỷ lệ kháng thể bất thường ở bệnh nhân tim mạch:}

Bảng 1. Tỷ lệ kháng thể bất thuờng ở bệnh nhân tim mạch:

\begin{tabular}{|c|c|c|}
\hline Số mẫu nghiên cứu & Số mẫu dương tính & Tỷ lệ (\%) \\
\hline 1680 & 11 & $0,65 \%$ \\
\hline
\end{tabular}

Nhận xét: tỷ lệ xuất hiện kháng thể bất thường ở bệnh nhân trước phẫu thuật là $0,65 \%$

3.2. Tỷ lệ kháng thể bất thường liên quan đến giới:

Bảng 2. Tỷ lệ kháng thể bất thường liên quan đến giới

\begin{tabular}{|l|c|c|c|c|}
\hline \multicolumn{1}{|c|}{ Giới } & Số mẫu nghiên cứu & Số mẫu (+) & Tỷ lệ (\%) & p \\
\cline { 1 - 4 } Nam & 832 & 4 & 0,48 & \multirow{2}{*}{$<0,05$} \\
\cline { 1 - 3 } & 848 & 7 & 0,83 & \\
\hline Tổng số & 1680 & 11 & 0,65 & \\
\hline
\end{tabular}

Nhận xét: Tỷ lệ kháng thể bất thường ở nữ là $0,83 \%$ và ở nam là $0,48 \%$ tỷ lệ xuất hiện kháng thể bất thường ở nhóm bệnh nhân nữ cao hơn bệnh nhân nam, sự khác biệt này có ý nghĩa thống kê.

\subsection{Tỷ lệ kháng thể bất thường liên quan tới nhóm tuổi:}

Bảng 3. Tỷ lệ kháng thể bất thuờng liên quan tới nhóm tuổi:

\begin{tabular}{|l|c|c|c|}
\hline \multicolumn{1}{|c|}{ Nhóm tuổi } & Số mẫu nghiên cứu & Số mẫu $(+)$ & Tỷ lệ (\%) \\
\hline $0-6$ tháng & 176 & 3 & 1,7 \\
\hline 7 tháng -18 tuổi & 702 & 4 & 0.57 \\
\hline $19-40$ tuổi & 207 & 2 & 0.97 \\
\hline $41-60$ tuồi & 351 & 2 & 0.57 \\
\hline$>60$ tuổi & 244 & 0 & 0 \\
\hline \multicolumn{1}{|c|}{ Tổng số } & 1680 & 11 & 0.65 \\
\hline
\end{tabular}

Nhận xét: Tỷ lệ kháng thể bất thường ở nhóm tuổi từ 0 đến 6 tháng tuổi là cao nhất $1,7 \%$, sau đó là nhóm tuổi từ 19 đến 40 tuổi $0,97 \%$, nhóm tuổi từ 7 tháng đến 18 tuổi và nhóm từ 41 đến 60 tuổi là 0,57\%, nhóm tuổi trên 60 tuổi chúng tôi không gặp trường hợp nào.

\subsection{Tỷ lệ kháng thể bất thường liên quan đến chẩn đoán lâm sàng:}

\begin{tabular}{|l|c|c|c|}
\hline Nhóm bệnh lý & Số mẫu nghiên cứu & Số mẫu (+) & Tỷ lệ (\%) \\
\hline Bệnh tim bẩm sinh & 966 & 8 & 0,83 \\
\hline Bệnh van tim & 424 & 3 & 0,71 \\
\hline Bệnh mạch máu & 213 & 0 & 0 \\
\hline Bệnh lý lồng ngực & 47 & 0 & 0 \\
\hline Tổng số & 1680 & 11 & 0,65 \\
\hline
\end{tabular}

Nhận xét: nhóm bệnh lý tim mạch bẩm sinh có tỷ lệ kháng thể bất thường cao nhất, sau đó là nhóm bệnh van tim là $0,71 \%$, còn nhóm bệnh lý mạch máu và lồng ngực chúng tôi không gặp trường hợp nào. 


\section{BÀN LUẬN:}

\subsection{Tỷ lệ xuất hiện kháng thể bất thường ở bệnh nhân trước mổ:}

Kết quả bảng 1 cho thấy qua sàng lọc 1680 bệnh nhân trước phẫu thuật tại Trung tâm tim mạch bệnh viện E tỷ lệ xuất hiện kháng thể bất thường là $0.65 \%$.

Kết quả này thấp hơn kết quả nghiên cứu của Trịnh Xuân Kiếm (1990: 11,4\%) và Bùi Thị Mai An (2012: 5.7\%), Phạm Quang Vinh (2012: 7,86\%) là do các tác giả trên nghiên cứu ở bệnh nhân có phản ứng tan máu muộn, bệnh nhân sau truyền máu hoặc bệnh nhân mắc các bệnh lý về máu, kết quả của chúng tôi thấp hơn so với các tác giả trên do đối tượng nghiên cứu của chúng tôi là toàn bộ những bệnh nhân trước phẫu thuật tim mạch hoặc trước khi truyền máu, các xét nghiệm sàng lọc kháng thể bất thường này thực hiện thường qui và khi bệnh nhân có kháng thể bất thường thì được lựa chọn đơn vị máu hòa hợp để truyền.

Kết quả của chúng tôi gần với kết quả của $\mathrm{Li}$ Hongxin (2011: 0,47\%), Tae-Hee Han (2012: 1,52\%), Tanya Sharma (2014: 0,09\%) do mẫu nghiên cứu của các tác giả này trên quần thể dân cư và những người tình nguyện khỏe mạnh, gần tương đồng với những mẫu nghiên cứu của chúng tôi ở những bệnh nhân trước mổ hầu hết là chưa được truyền máu trước đó.

\subsection{Mối liên quan giữa sự xuất hiện} kháng thể bất thường với một số yếu tố:

Kết quả ở bảng 2 cho thấy: Tỷ lệ kháng thể bất thường ở nữ là $0,83 \%$ và ở nam là $0,48 \%$ tỷ lệ xuất hiện kháng thể bất thường ở nhóm bệnh nhân nữ cao hơn bệnh nhân nam nhận xét này của chúng tôi phù hợp với Bùi Thị Mai An, Trịnh Xuân Kiếm, Li Hongxin. Sở dĩ như vậy vì ở phụ nữ có thể xuất hiện kháng thể bất thường do bất đồng nhóm máu ngoài hệ $\mathrm{ABO}$ trong quá trình chửa đẻ. Sự khác biệt này có ý nghĩa thống kê $(\mathrm{p}<0,05)$.
Kết quả ở bảng 3 chúng tôi chia độ tuổi của bệnh nhân ra các nhóm tuổi, ở nhóm tuổi từ 0 đến 6 tháng có tỷ lệ kháng thể bất thường cao nhất $(1,7 \%)$, do ở nhóm tuổi này có liên quan đến kháng thể của mẹ vẫn còn lưu lại trong cơ thể trẻ sau khi sinh. Nhóm tuổi từ 19 đến 40 tuổi có tỷ lệ kháng thể bất thường là $0,97 \%$, ở nhóm tuổi này các kháng thể trong cơ thể đã hình thành và phát triển mạnh mẽ, nhất là sau khi được tiếp xúc với các kích thích kháng nguyên cơ thể sẽ sinh ra kháng thể chống lại kháng nguyên đó. Nhóm tuổi từ 7 tháng đến 18 tuổi và nhóm tuổi từ 41 đến 60 tuổi có tỷ lệ kháng thể bất thường là $0,57 \%$. Riêng nhóm tuổi trên 60 tuổi do số lượng bệnh nhân trong nghiên cứu này còn hạn chế nên chúng tôi chưa phát hiện được trường hợp nào.

Do số lượng bệnh nhân nghiên cứu của chúng tôi chưa đủ lớn nên sự khác biệt của tỷ lệ kháng thể bất thường giữa các nhóm tuổi này không có ý nghĩa thống kê với $\mathrm{p}>0,05$.

Kết quả ở bảng 4. Nhóm bệnh nhân mắc bệnh tim bẩm sinh có tỷ lệ kháng thể bất thường cao nhất $0,83 \%$, trong nhóm bệnh tim bẩm sinh này thường có độ tuổi trẻ hơn, dễ bội nhiễm đường hô hấp. Nhóm bệnh lý của van tim có tỷ lệ kháng thể bất thường là $0,71 \%$, nhóm này thường liên quan đến nguyên nhân thấp tim, nhiễm khuẩn đó cũng là những yếu tố kháng nguyên kích thích cơ thể sinh kháng thể. Nhóm bệnh lý mạch máu và lồng ngực do số lượng mẫu chưa đủ lớn nên chúng tôi chưa gặp bệnh nhân nào có kháng thể bất thường.

Có những kháng thể bất thường xác định được bản chất kháng thể, nhưng cũng có nhưng kháng thể bất thường mà chưa xác định được bản chất của kháng thể bất thường đó. Khi gặp những mẫu kháng thể bất thường dương tính chúng tôi tiến hành xét nghiêm lựa chọn trước những đơn vị máu phù hợp với mẫu máu của bệnh nhân để chuẩn bị cho truyền máu trong cuộc phẫu thuật đảm bảo an toàn tránh những tai biến tan máu muộn sau truyền máu gây nên. Vì vậy sàng lọc 
kháng thể bất thường cho tất cả bệnh nhân trước truyền máu là rất cần thiết để hạn chế nguy cơ do bất đồng miễn dịch.

\section{KẾT LUẬN}

Qua xét nghiệm sàng lọc kháng thể bất thường cho 1680 bệnh nhân tim mạch tại Trung tâm tim mạch bước đầu chúng tôi rút ra kết luận sau:

1. Tỷ lệ kháng thể bất thường ở bệnh nhân tim mạch tại Trung tâm tim mạch Bệnh viện $\mathrm{E}$ (từ tháng 6 năm 2013 đến tháng 9 năm 2014) qua thực hiện xét nghiệm sàng lọc kháng thể bất thường là $0,65 \%$. Tỷ lệ dương tính ở bệnh nhân nữ $0,83 \%$ và bệnh nhân nam là $0,48 \%$.

2. Tỷ lệ kháng thể bất thường có liên quan đến tuổi, giới và chẩn đoán lâm sàng.

3. Tất cả bệnh nhân có kháng thể bất thường đều được xét nghiệm chọn lọc trên nhiều túi máu để chọn ra túi máu phù hợp dự trữ sẵn sàng cho truyền máu khi phẫu thuật hạn chế các tai biến truyền máu muộn.

\section{KIẾN NGH!}

1. Cần làm xét nghiệm sàng lọc kháng thể bất thường ở tất cả các bệnh nhân tim mạch có chỉ định phẫu thuật.

2. Đối với các trường hợp kháng thể bất thường dương tính cần làm thêm xét nghiệm định danh kháng thể bất thường.

\section{TÀI LIỆU THAM KHẢO}

1. Bùi Thị Mai An (2012) "nghiên cứu kết quả sàng lọ và định danh kháng thể bất thuờng ở bệnh nhân bị bệnh máu tại viện Huyết học- Truyền máu Trung uơng 2009 - 2011", tạp chí y học Việt Nam, tập 396, trang $484-488$.

2. Nguyễn Thị Thanh Mai (2005), Nghiên cứu các kháng thể bất thường kháng hồng cầu ở một số đối tuợng tại Bệnh viện nhi trung ương, Luận án tiến sỹ sinh học, Tr. 11-20.

3. Phạm Quang Vinh (2012), một số đặc điểm lâm sàng xét nghiệm ở bệnh nhân bị bệnh máu có kháng thể bất thường hệ hồng cầu, tạp chí y học Việt Nam, tập 396, trang 428-431.

4. Quy chế truyền máu - 2007 và một số văn bản quy phạm pháp luật về truyền máu. Bộ Y tế.

5. Trần Văn Bé, Miễn dịch huyết học và truyền máu, Lâm sàng huyết học, 1998, tr. 312 - 350.

6. Trịnh Xuân Kiếm, Bạch Quốc Tuyên, Trịnh Kim Ảnh (1990), Kháng thể bất thuờng, nguyên nhân phản úng tan máu muộn tại Bệnh viện Chơ Rẫy, Y học thực hành số 5 tập 228, tr.14-15.

\section{Tiếng Anh}

7. Ki-Ho Ko, Byung-Hoon Yoo, Kye-Min Kim, Woo-Yong Lee, Jun-Heum Yon, Ki-Hyuk Hong, and Tae-Hee Han "Frequency of unexpected antibody and consideration during transfusion” Korean J Anesthesiol. 2012 May; 62 (5):412-417

8. Neeraj Garg, Tanya Sharma, Bharat Singh "Prevalence of irregular red blood cell antibodies among healthy blood donors in Delhi population" Volume 50, Issue 3, June 2014, Pages 415-417.

Xianjun Ma; Jing Fu; Zhonghua Chu; Xiuling Cao; Hongxin Li "Irregular-antibody Screening in Shandong Region and Clinical Impact on Blood Transfusion-a review of case from 2008 to 2010" December 2011, Journal of Convergence Information Technology; Dec 2011, Vol. 6 Issue 12, p338. 